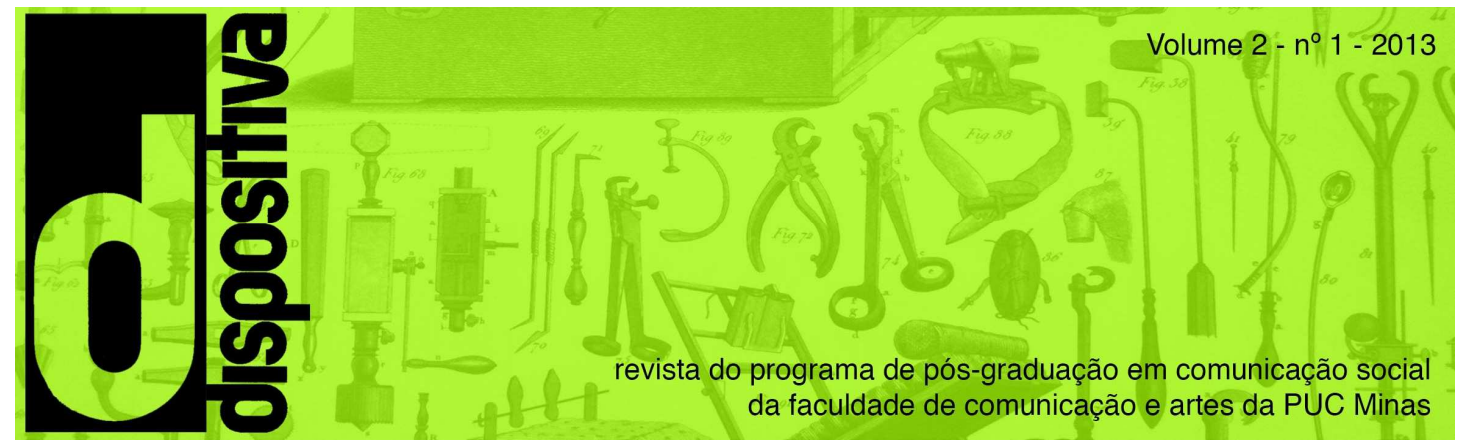

\title{
Dissertações defendidas entre outubro de 2012 e julho de 2013 - PPGCom - PUCMinas
}

PASSOS, Mariana Rezende dos

O Twitter como trincheira de luta: um estudo sobre o microblog de Hugo Chávez //Twitter as a trench of fight: a study on the microblog of Hugo Chávez

Orientadora: Teresinha Maria de Carvalho Cruz Pires

\section{Resumo}

A recente apropriação de novas mídias por parte de atores políticos, em períodos eleitorais ou não, e as consequentes mudanças na prática e no discurso político acabam por exigir uma evolução também nos estudos da área de comunicação e política; tanto em termos de elaborações teóricas quanto metodológicas. Partindo desse contexto, a pesquisa propôs a investigação das táticas discursivas de Hugo Chávez no ambiente do Twitter (entre 01 de outubro de 2011 e 14 de outubro de 2012) considerando sua percepção do microblog como uma trincheira de luta. A batalha travada por Chávez no microblog, no corpus delimitado, se subdivide em duas: A Batalha de Carabobo, referente especificamente à campanha eleitoral, e a Batalha de Ideias, que perpassa por todo o período analisado e diz respeito à divulgação do seu projeto de governo: o socialismo do século XXI. Para consecução de tal objetivo foi necessária uma revisão bibliográfica sobre o chavismo e sobre a trajetória política e midiática de Chávez que foi reeleito em outubro de 2012, o que garantiu ao mandatário governar seu país até 2019, contabilizando vinte anos sob o comando da Venezuela; e um estudo aprofundado sobre o funcionamento do Twitter. Nesse sentido acredita-se que a pesquisa ora apresentada possa colaborar para o fomento de novos conhecimentos para os estudos da área de Comunicação Política.

\begin{abstract}
The recent appropriation of new mediums by political actors in electoral periods or not, and the consequent changes in political practice and political discourse require a change likewise in the area of communication and political studies, in terms of theoretical elaborations and methodological. From this context, the research proposes to investigate the discursive tactics of Hugo Chavez on Twitter (between 1 October 2011 and 14 October 2012) considering his perception of the microblog as a trench of fight. The battle that Chavez wages in the microblog, in the delimited corpus, is divided into two: the Battle of Carabobo, referring specifically to the electoral
\end{abstract}


campaign, and the Battle of Ideas, which permeates the whole period and relates to the disclosure of his government project: the XXI century socialism. To achieve this goal it was necessary to review the literature of the chavismo and the political and media path of Chavez - who was reelected in October 2012, which guaranteed that he can govern his country until 2019, accounting twenty years under the command of Venezuela; and a thorough study on the functioning of Twitter. In this sense it is believed that the aim of the research proposed here can contribute to the development of new knowledge for studies in the area of Political Communication.

MOL, Vanessa Bueno

O caso Arezzo: um estudo sobre a interação entre organizações e sociedade nas redes sociais na internet //The case Arezzo: a study on the interaction between organizations and society on the internet's social networks

Orientadora: Ivone de Lourdes Oliveira

\section{Resumo}

O objetivo deste trabalho é, através do estudo de caso das repercussões em torno do lançamento da coleção Pelemania da Arezzo, analisar o processo de interação entre organizações e sociedade nas redes sociais na internet. A temática se inscreve na perspectiva sistêmica, que compreende a comunicação como ação descentralizada que se estabelece de forma não hierárquica entre sistemas que se influenciam mutuamente e co-evoluem a partir de perturbações que um imprime ao outro. Sob esse viés, as organizações são entendidas como sistemas sociais operacionalmente fechados, que empreendem uma série de esforços a fim de preservar sua ordem interna; mas que, ao mesmo tempo, também precisam interagir com os outros sistemas e com o meio em busca de sua própria evolução. Agrupadas sob a categoria de resposta social, as manifestações de enfrentamento da sociedade às organizações também são percebidas, neste trabalho, como um dos inúmeros sistemas sociais capazes de influenciar e modificar a conduta organizacional. Nesse sentido, buscamos colocar em relação, a partir da página oficial da Arezzo e de um perfil declaradamente contrário à empresa, ambos presentes no Facebook, tanto os esforços organizacionais em tentar se proteger de perturbações externas potencializadas pelas redes sociais; como também as iniciativas empreendidas pela sociedade no sentido de pressionar a empresa a mudar de postura. Para isso, adotamos metodologicamente o modelo de Fairclough (2001), a partir do qual pudemos captar tanto a tentativa da organização em naturalizar suas ações e exercer seu poder sobre os demais interlocutores, como a reinterpretação ou apropriação que a sociedade imprimiu a esse discurso, como instrumento de contestação, constituindo-se numa forma de resistência.

\section{Abstract}

The work here presented strives to, through the repercussions of the launching of Arezzo's Pelemania collection, analyze the interaction process between organizations and society on the internet's social networks. This theme is part of the systemic perspective, which understand communication as a decentralized action that presents itself in a non-hierarchy fashion among systems that influence each other and coevolve via the disturbance that one causes another. In this point of view, organizations 
are comprehended as operationally closed social systems that undertake a series of actions that intend to preserve it's internal order. But, in doing so, at the same time, also needs to interact with other systems and with the environment in which they operate to seek it's own evolution. Gruped under the social response category, society's confrontation actions against organizations are also perceived here as one of the incalculable social systems with enough power to influence and modifty organizations behavior. In this respect, we seek to confront, analyzing Arezzo's ofical profile and another openly against the company's policy, both on Facebook, the organization efforts to shield itself from external disturbence potencialized by social networking, as well as society based initiative to press the company, demanding it to change it's way of doing business. To that end, it was used, metodologically speaking, the model developed by Fairclough (2001), which allowed to capture both the organization's efforts to naturalize it's actions and put into practive it's power over the other interlocutors, as well as the reinterpretations or apropriations that society makes of this efforts as instruments of confrontation that constitute a way of resistance.

\section{CAMPOS, Luiza Mara Reis Furtado}

A Web 2.0 no ambiente interno das organizações: um estudo de caso sobre as intranets sociais de Cemig e Unimed-Rio//The Web 2.0 at the organizations internal environment: a study case on social intranets of Cemig and Unimed-Rio.

Orientadora: Ivone de Lourdes Oliveira

\section{Resumo}

O objetivo deste trabalho é compreender se há, por parte dos empregados das organizações Cemig e Unimed-Rio, o reconhecimento do espaço relacional que essas empresas propõem ao transformarem suas intranets em ambientes desenvolvidos sob a lógica da Web 2.0, conforme a perspectiva conceitual adotada. A escolha dessas organizações como objeto empírico justifica-se pelo fato de terem reformulado suas intranets, com o objetivo de transformá-las em ambientes regidos pelos princípios da Web 2.0, por meio da implementação de recursos que possibilitassem aos empregados espaços de colaboração e a descentralização da gestão do conteúdo. A pesquisa é desenvolvida a partir do paradigma relacional, segundo o qual a comunicação é vista globalmente, como um processo em que interlocutores em interação produzem e compartilham sentidos, em um dado contexto sócio-histórico. Nessa perspectiva, este estudo abandona a visão unilateral e parcial da comunicação, que considera apenas os resultados das estratégias mercadológicas e institucionais das empresas e não leva em conta as percepções dos demais interlocutores envolvidos. Assim, encontrou-se na análise crítica de discurso, segundo a abordagem sugerida por Fairclough, uma proposta teórico-metodológica coerente com o propósito desta investigação. Portanto, a partir de categorias que possibilitassem encontrar a relação dialética proposta pelo autor, analisaram-se os discursos dos empregados e também das organizações acerca das intranets. A hipótese da pesquisa confirmou-se a partir dos resultados, que evidenciaram as contradições existentes entre o que as empresas dizem e a apreensão desse discurso por parte dos empregados.

\section{Abstract}


This study aims to understand if there is an acceptance of the relational space of the Cemig and Unimed-Rio employees that these companies propose when they transform their intranets into settings develop by the logic of the Web 2.0 according to the conceptual perspective adopted. The choice of these two organizations as an empirical object is due to the reformulation of their intranets, with the aim to transform them into settings ruled by the Web 2.0 principles through the implementation of means which enable the employees spaces of collaboration and the decentralization of the content management. The research is developed from the relational paradigm whereby the communication is seen globally as a process which the interlocutors in interaction produce and share feelings in a specific social historical context. From this perspective, this study abolish the unilateral view and partial of communication which considers only the marketing strategies and institutional results of the companies and does not regard the perceptions of the others interlocutors involved. Thus, it was found in the Critical Discourse Analysis, according to the approach suggested by Fairclough, a theoretical methodological proposal consistent with the purpose of this research. Therefore, from the categories which would enable to detect the dialectic relation proposed by the author, the discourses of the employees were analyzed and so the organizations about the intranets. The hypothesis of this study corroborated from the results which stated evidence the contradictions between what the companies say and the comprehension about this speech by the employees.

\section{Astrologia audiovisual: uma análise semiótica das estratégias de enunciação do programa "No Astral"// Audiovisual Astrology: A semiotic analysis of enunciation's strategies from "No Astral"}

\section{DINIZ, Moema Najjar}

Orientador: Julio Pinto

\section{Resumo}

Esta dissertação realizou um estudo das estratégias de enunciação utilizadas pelo Programa No Astral da emissora GloboNews Television (GNT) para se aproximar da recepção. Aplicou-se a metodologia de análise semiótica aos programas exibidos no ano de 2012 e ao contexto social de onde partiu a enunciação. Além disso, buscou-se analisar os elementos novos que o programa trouxe, a relevância e os sintomas percebidos em No Astral que implicam conclusões sobre a sociedade contemporânea. Durante a pesquisa, percebeu-se que o programa utiliza estratégias sensíveis para se aproximar de seu receptor, privilegiando em sua enunciação os testemunhos de pessoas comuns e celebridades. Estas personagens são apresentadas como pessoas normais, gente como a gente, a fim de gerar maior aproximação e servir de modelo de identidade para o público do programa. A pesquisa revelou que No Astral dissemina valores por meio de estratégias sutis e de envolvimento sensorial. O programa visa o entretenimento e altera 0 tradicional contrato de leitura da astrologia nas mídias. 


\begin{abstract}
This search conducted a study of the strategies used by the enunciation from GNT (GloboNews Television) program, No Astral, to approach the reception through a semiotic analysis of programs shown, and social context of the enunciation. We applied the methodology of semiotic analysis to programs shown in 2012 and the social context in which he left the enunciation. Furthermore, we sought to examine the new evidence that the program has brought the relevance and perceived symptoms in No Astral that imply conclusions about contemporary society. During the research, it was noticed that the program uses sensitive strategies to approach their receiver, focusing on its enunciation the testimonies of ordinary people and celebrities. These characters are presented as normal people, "people like us" in order to generate greater contact and serve as a model of identity. The research revealed that in Astral disseminates values through subtle strategies and sensory involvement. The program aims to change the traditional entertainment and reading contract of astrology in the media.
\end{abstract}

BARBOSA, Maximiliano Henrique

\title{
OUTDOOR DE ARTE: território de interseção// BILLBOARD ART: territory of intersection
}

Orientador: Eduardo Antonio de Jesus

\section{Resumo}

Essa pesquisa tem como objeto o uso do outdoor para prática artística. $\mathrm{O}$ recorte para análise é o livro-catálogo Billboard Art on the Road (HEON; DIGGS; THOMPSON, 1999) produzido para exposição no Mass MoCA, em Massachussets, EUA. Foram usados como principais recursos teóricos os conceitos de midiatização, experiência estética e dispositivo. O outdoor de arte foi enfocado como um evento estético na interseção entre os campos da arte e da publicidade no espaço urbano contemporâneo. Além de uma análise geral do funcionamento do outdoor de arte foram feitas análises das obras Fear and Hate, de Barbara Kruger (1992), Untitled (Bed), de Felix Gonzalez-Torres (1992) e Met Museum, do coletivo Guerrilla Girs (1999).

\section{Abstract}

This research aims the use billboards to artistic practices. The cutout for analysis is the book-catalog Billboard Art on the Road (HEON; DIGGS; THOMPSON, 1999), produced for an exhibition at Mass MoCA in Massachusetts, USA. The main theoretical resources were the concepts of mediatization, aesthetic experience and apparatus. The chosen approach is the billboad art as an aesthetic event on the intersection between the fields of art and advertising in contemporary urban space. In addition to an overview of the operation of billboard art, specific analyzes were made regarding the 
following works: Barbara Kruger's, Fear and Hate (1992), Felix GonzalezTorres, Untitled (Bed) (1992) and Met Museum (1999) by the collective Guerrilla Girs

MENDES, Ana Paula Giberti Oliveira

Redes internacionais midiatizadas da blogosfera da Segurança Pública: estudo do processo comunicacional durante o período da mobilização reivindicatória dos agentes da Segurança Pública de Minas Gerais//

\author{
Orientadora: Maria Ângela Mattos
}

\title{
RESUMO
}

Esta pesquisa objetivou investigar o processo comunicacional das redes midiáticas, em particular da blogosfera da Segurança Pública (SP). Para isso, utilizou-se como estudo de caso o blog da Renata, que explora conteúdos midiáticos relacionados à $\mathrm{SP}$ e temáticas correlatas à Defesa Social no Estado de Minas Gerais. O suporte foi escolhido por revelar a diversidade interacional de atores da SP nas redes e a convergência do ambiente entre mídia informal, comercial e institucional, por instigar reflexões sobre o uso da rede como um ambiente propício à mobilização e compartilhamento de questões e ações de interesses individuais e coletivos. Para o monitoramento da mídia, investigou-se a interação do blog da Renata no contexto da mobilização reivindicatória salarial da SP em Minas Gerais, no ano de 2011. Como recorte temporal, acompanhou-se os meses de abril a julho, identificados em três períodos: pré-mobilização reivindicatória, mobilização e pós-mobilização reivindicatória, justificado pelo rico e complexo ambiente de interações sociais, mediações simbólicas e disputas de sentido entre atores da SP. A pesquisa fundamentou-se em teorias sobre redes, capital social, esfera pública, deliberação, movimentos sociais, mobilização, midiatização como processo interacional de referência, interação midiatizada e sistema de resposta social, além dos estudos sobre blog e blogosfera da SP. A metodologia compreendeu a revisão da literatura e o monitoramento do processo comunicacional no blog da Renata durante sua atuação no período da mobilização reivindicatória dos agentes da SP a partir de duas categorias analíticas: a dinâmica interacional midiática e o sistema de resposta social. Compreendeu ainda entrevistas, análise e interpretação dos seus conteúdos, postagens, interagendamentos com outros blogs e meios de comunicação institucionais e comerciais.

\section{ABSTRACT}

This study aimed to investigate the process of communication media networks in particular, the blogosphere Public Safety. For this, we used as a case study Renata's blog that explores media content related to Public Security and the Social Defense related topics in the State of Minas Gerais Brazil. Support has been chosen to reveal the diversity of actors interactional Public Safety networks and the convergence between media environment alternative, 
commercial and institutional, for instigating reflections on the use of the network as an environment for mobilization and sharing of issues and actions of personal interests and collective.To monitor the media, we investigated the interaction of Renata's blog in the context of mobilization vindicatory wage of Public Safety at Minas Gerais, in 2011. As time frame, followed up the months from April to July, identified in three periods: before-vindicatory mobilization, mobilization and post-mobilization vindicatory, justified by the rich and complex environment of social interaction, symbolic mediations and disputes between players in order Public Security. The research was based on theories of networks, social capital, public sphere, deliberation, social movements, mobilization, mediatization as interactional process reference, mediated interaction and social response system, in addition to studies on the blog and blogosphere Public Safety. The methodology included a literature review and monitor the communication process Renata's blog on his performance during the period of mobilization vindicatory Public Safety Officers from two analytical categories: a dynamic interactive media system and social response. Also comprised interviews, analysis and interpretation of their content, posts, inter sheduling with other blogs and media institutional and commercial. 